\title{
Students' perceptions of the use of technological tools that facilitate self-regulated English language learning
}

\section{Percepciones de los estudiantes sobre el uso de herramientas tecnológicas que facilitan el aprendizaje autorregulado del idioma inglés}

1 Sarah Jacqueline Iza Pazmiño

(iD) https://orcid.org/0000-0002-8059-7868 Universidad Técnica de Ambato. Facultad de Ciencias Humanas y de la Educación. Carrera de Pedagogía de los Idiomas Nacionales y Extranjeros sj.iza@uta.edu.ec

2 Verónica Elizabeth Chicaiza Redin Universidad Técnica de Ambato. Facultad de Ciencias Humanas y de la Educación. Carrera de Pedagogía de los Idiomas Nacionales y Extranjeros ve.chiciaza@uta.edu.ec

3 Edgar Guadia Encalada Trujillo (iD) https://orcid.org/0000-0001-8843-4804 Universidad Técnica de Ambato. Facultad de Ciencias Humanas y de la Educación. Carrera de Pedagogía de los Idiomas Nacionales y Extranjeros eg.encalada@uta.edu.ec

4 Cristina del Rocío Jordan Buenaño (iD) https://orcid.org/0000-0003-1938-1379 Universidad Técnica de Ambato. Facultad de Ciencias Humanas y de la Educación. Carrera de Pedagogía de los Idiomas Nacionales y Extranjeros cristinadjordanb@uta.edu.ec

Artículo de Investigación Científica y Tecnológica Enviado: 05/12/2021

Revisado: $12 / 12 / 2021$

Aceptado: $12 / 01 / 2022$

Publicado:08/03/2023

DOI: https://doi.org/10.33262/concienciadigital.v6i1.4.1982

del R. (2023). Students' perceptions of the use of technological tools that facilitate self-

Cítese: regulated English language learning. ConcienciaDigital, 6(1.4), 6-19. https://doi.org/10.33262/concienciadigital.v6i1.4.1982

CONCIENCIA DIGITAL, es una Revista Multidisciplinar, Trimestral, que se publicará en soporte electrónico tiene como misión contribuir a la formación de profesionales competentes con visión humanística y crítica que sean capaces de exponer sus resultados investigativos y científicos en la misma medida que se promueva mediante su intervención cambios positivos en la sociedad. https://concienciadigital.org 


\section{Palabras}

claves:

aprendizaje

autorregulado, proceso de aprendizaje, TIC, educación virtual, plataformas en línea.

\section{Keywords:}

self-regulated

learning;

learning

process; ICTs;

virtual

education; online platforms.

\section{Resumen}

Este estudio tiene como objetivo identificar en qué medida el uso de herramientas tecnológicas facilita el aprendizaje autorregulado entre los estudiantes en formación que estudian inglés. La metodología empleada para este estudio fue un diseño de encuesta y se administró un cuestionario a 497 estudiantes de la Zona 3. Los resultados muestran que las estrategias más utilizadas para autorregular el aprendizaje del idioma inglés de los estudiantes están relacionadas con la búsqueda de información, revisión y memorización, revisión o repaso de apuntes y / o libros, y actividades de autoevaluación. En cuanto a la frecuencia de uso de herramientas digitales para autorregular el aprendizaje del idioma inglés, el $45 \%$ de los participantes mencionó que siempre usa estas herramientas. Además, el 63\% de los estudiantes considera que el uso de herramientas tecnológicas facilita el aprendizaje autorregulado del idioma inglés. Se puede concluir que la importancia de las herramientas tecnológicas y su aplicación en el contexto académico facilita el aprendizaje de los estudiantes. También se recomienda realizar más investigaciones en el área para explorar las fortalezas que tienen las herramientas TIC para desarrollar el aprendizaje autorregulado.

\section{Abstract}

This study aims to identify to what extent the use of technological tools facilitates self-regulated learning among pre-service students studying English. The methodology employed for this study was a survey design and a questionnaire was administered to 497 students studying at Zone 3. The results show that the most used strategies to self-regulate students' English language learning are related to the search of information, review and memorization, revision or review of notes and/or books, and self-assessment activities. Regarding the frequency of use of digital tools to self-regulate English language learning, $45 \%$ of the participants mentioned that they always use these tools. Furthermore, 63\% of students considered that the use of technological tools facilitates selfregulated English language learning. It can be concluded that the importance of technological tools and their application in the academic context facilitates students' learning. It is also recommended to do more research in the area to explore the strengths that ICT tools must develop self-regulated learning. 


\section{Introduction}

The fast technological development in which the knowledge society is moving forward has changed students' patterns and structures in learning. The internet, digital platforms, and media have been responsible for changing the usual context of education. These changes have promoted the creation of novel and innovative methodologies in the teaching-learning process (Escobar et al., 2021), where technology plays a fundamental role. According to the latest insights on how today's modern learners prefer to use technology and how their learning has an impact if they use technology, it was revealed that the use of technology and modern computer tools have significantly increased the levels of learning and interactivity as the transfer of knowledge becomes easier, convenient and effective (Raja \& Nagasubramani, 2018).

Technology has always been used in the teaching and learning process and its advances have shaped the mode of education that institutions offer to their students. Technology, therefore, cannot be seen as an isolated component of learning, it needs to be integrated to the whole teaching and learning process since it has become a fundamental part of everyday life, not only for students, but also for people in general (Ahmadi, 2018). Familiarity with the concept of using modern technology is not simply limited to the use of modern gadgets and devices but is due to the introduction of innovative teaching methods and systems that facilitate faster and more complete learning. In this sense, according to prevailing pedagogical theories, by utilizing the learning potential of technology, students are better able to acquire and refine both their knowledge and language skills (Lion, 2019). It is for this reason that the use of technology in English language teaching consolidates the integrated view of the modern media system and the association with other components that benefit learners in achieving the required outcomes.

The inclusion of ICT in education has led to the emergence of new pedagogical practices, in which the student has gradually become the main actor of their learning thus moving forward to self-regulated learning. Self-regulated learning has become a key concept especially in higher education, since it offers the possibility of forming autonomous students, capable of managing their study process and develop skills that will ensure success throughout their lives either inside or outside the academic field (Flores \& Marquez, 2020).

The use of modern technology in English language teaching encompasses an innovative application of methods, tools, materials, devices, systems and strategies that are directly relevant to English language teaching and lead to the achievement of the desired learning objectives. Technology is now generally accepted as an important educational and innovative tool in a variety of teaching and learning contexts; and ELT cannot be an 
exception since it offers several potential opportunities to enhance both the content and delivery of pedagogies (Alqahtani, 2019).

In autonomous learning, it is not enough just to know the contents of a particular subject, but to have the initiative, confidence, effort and persistence to successfully achieve the academic challenges using different strategies adapted to the different learning environments and resources available at any given time (Flores \& Marquez, 2020). Indeed, around language teaching both the initiatives taken by learners and the persistence to achieve their goals together with the pedagogical strategies applied and resources used constitute those factors relevant to second language acquisition (Luján, 2014).

\section{The use of ICT in English language teaching}

Information and communication technologies have played a very important role in the teaching of English throughout the ages. Their application has contributed to the improvement of learners' skills. For example, the use of the Internet is one of the most effective ways to facilitate the understanding of the English language since it is possible to watch videos, learn new vocabulary with real images, engage in conversation with native English speakers through video conferences, among other activities that can be very useful and supportive to reinforce the knowledge previously acquired in the classroom (Jiménez, 2018).

The adoption of ICT in the educational context has generated a new learning environment in which the students have become the main players of their learning. The creation of this environment has been possible due to time and flexibility offered by a virtualized context leading to a revolution in which information and communication technologies converge forming new pedagogical and educational paradigms (Suárez \& Custodio, 2014). ICT has been responsible for providing a wide variety of resources which have allowed teachers to break traditional teaching paradigms and focus more on the students' needs. This, however, has been possible by incorporating a series of technological elements into the academic processes. Elements that allow faster and more effective communication between the different stakeholders (Andrade et al., 2020). Hernandez (2017) mentions that the incorporation of ICT in education has become a process whose implications go far beyond the technological tools that make up the educational environment. We are talking about didactic construction and the way in which meaningful learning can be built and consolidated based on technology.

Another advantage of the incursion of ICT in teaching and learning processes is that it also greatly aids collaborative learning by promoting teaching and learning through the participation of groups of students, who jointly solve problems or simply create projects. ICT therefore creates a great social environment where different students can share diverse perspectives and learn from each other. 


\section{Strategies for learning English}

To achieve the learning goals of a foreign language, students need to practice the language and interact with other people in real contexts. This interaction will greatly facilitate the language acquisition. In addition, to make learning easier, it is necessary to strengthen the development of oral, written and listening skills (Díaz et al., 2018), using effective ELT methods.

There are several methods relevant to ELT, each of them supported especially by didactic strategies and the use of ICT. For instance, Computer-assisted language learning (CALL) which is defined as all activities that employ computers and technological applications teach second and foreign languages (Martínez et al., 2019), focusing on the following competences, as shown in figure 1:

\section{Figure 1}

\section{ICT Competences}

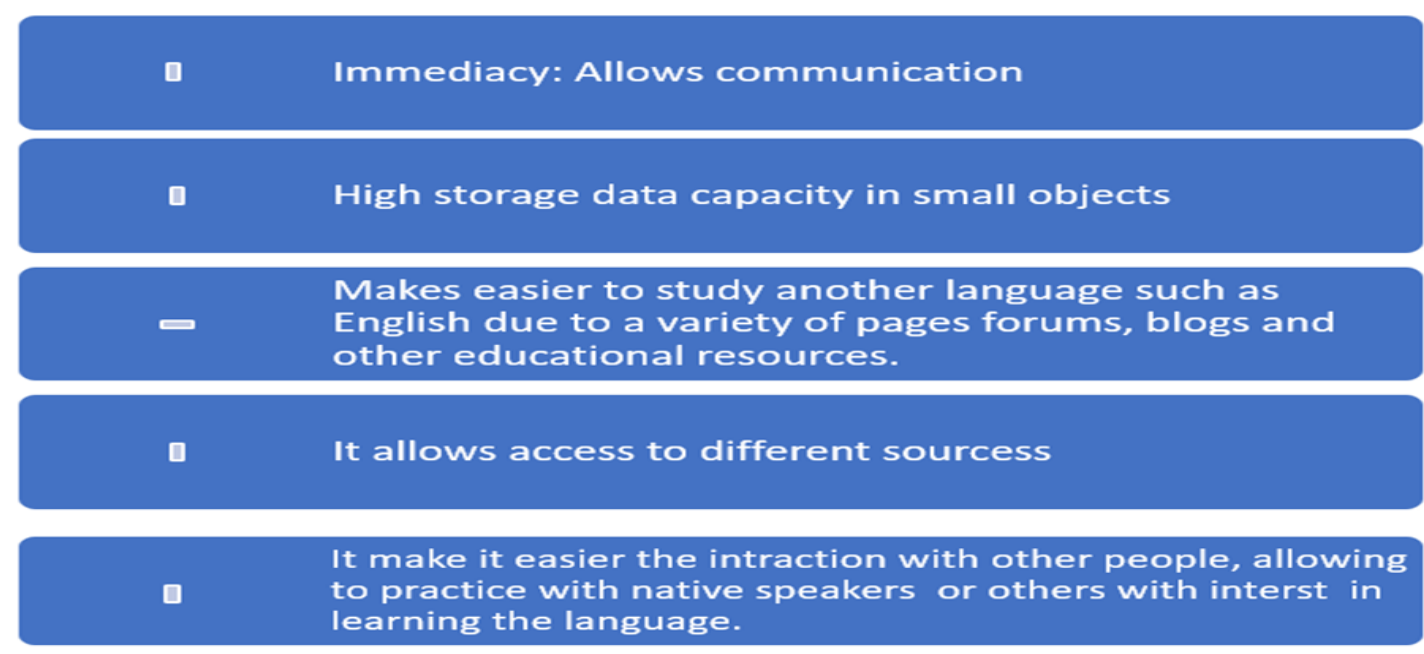

Note: Another view about the developing technological competences in the mastery of another language. Source: Adapted from the article: Use of ICTs in English Learning (Martínez et al., 2019).

\section{Self-regulation of learning}

It represents an active cognitive process in which learners set goals that direct their learning. It also aims to supervise (monitor) and regulate students' cognition, motivation and behavior. Self-regulated learning generates among students a sense of satisfaction and motivation to study and engage in learning-related activities (Díaz et al., 2017).

Self-regulation includes the implementation of individual thinking and behavioral strategies to regulate students' motivation to learn, to know what skills and knowledge they possess, to identify their learning needs, and to monitor their study habits. This with the intention to adjust to the learning demands and ultimately to regulate the whole learning process. 
What characterizes students as self-regulators of their learning is not the isolated use of strategies, but their personal initiative, and their perseverance to learn. Perseverance that is manifested regardless the context in which learning occurs. For this reason, selfregulation of learning is fundamental for academic achievement, since it is associated with personal work, intense involvement in study time and with self-regulatory behavior.

\section{Methodology}

This study employed a survey design whose objective was to identify the students' perceptions of the use of technological tools to facilitate self-regulated learning. To collect data a 19-item questionnaire was constructed. To analyze the data descriptive and inferential statistics were used.

To construct the questionnaire, it was necessary to develop bibliographic research, namely, books, journals, and other documents. Once the questionnaire was validated and piloted, it was administered to the total population of preservice students (497) studying in three universities located in the Zone 3. Out of the 497 students, 490 with a variety of English levels responded the questionnaire as presented on table 1.

Table 1

\begin{tabular}{lrr}
\multicolumn{3}{c}{ Population } \\
\hline Description & Frequency & Percentage \\
\hline A1 Beginner & 75 & $15 \%$ \\
A2 High Beginner & 54 & $11 \%$ \\
A2 + Low Intermediate & 48 & $10 \%$ \\
B1 Intermediate & 135 & $28 \%$ \\
B1+ High Intermediate & 81 & $16 \%$ \\
B2 Upper Intermediate & 73 & $15 \%$ \\
B2+ Low Advance & 19 & $4 \%$ \\
C1 Advance & 5 & $1 \%$ \\
Total & 490 & $100 \%$ \\
\hline
\end{tabular}

Source: Survey applied by the authors

\section{Results}

This section presents the results of the main items of the instrument applied. In this sense, three questions were selected to measure the variables under study, with the following findings:

About the strategies commonly used by those involved in the study to self-regulate their English language learning, divided criteria are recorded. The item proposed provided the facility to select more than one option, which allows for a broader horizon on the 
perceptions of the participants in the research. In this sense, the following results are available, as shown in table 2: of the $100 \%$ of the students surveyed, $65.1 \%$ mentioned that the strategy they use to self-regulate their English language learning is related to searching for information, $61.6 \%$ associate it with reviewing and memorizing, $54.3 \% \mathrm{opt}$ for reviewing or revising notes and books, $34.1 \%$ carry out self-assessment activities, $29.4 \%$ carry out data collection, $28 \%$ carry out planning and planning activities, $28 \%$ carry out planning activities, and $28 \%$ carry out self-assessment activities, $28 \%$ develop planning activities and establish goals and subgoals, $18.4 \%$ carry out tasks of organization and transformation of information, $17.6 \%$ carry out self-direction activities, $14.5 \%$ seek academic assistance, $14.3 \%$ opt for structuring the environment and finally, the remaining $9.6 \%$ use strategies of self-assignment of positive and negative feelings that allow them to self-regulate their learning, as shown in table 2.

Table 2

Self-regulation strategies

\begin{tabular}{lccc}
\hline & Answers & Percentage of cases \\
\cline { 2 - 2 } & $\mathbf{N}$ & \\
\hline Self-directed/chosen and carried out by the learner & 86 & $17,6 \%$ \\
himself/herself & 167 & $34,1 \%$ \\
Self-assessment & 71 & $14,5 \%$ \\
Seeking academic assistance & 319 & $65,1 \%$ \\
Search for information & 70 & $14,3 \%$ \\
Structuring the environment & 90 & $18,4 \%$ \\
Organization and transformation of information & 137 & $28,0 \%$ \\
Planning and setting goals and subgoals & 144 & $29,4 \%$ \\
Data collection & 302 & $61,6 \%$ \\
Review and memorization & 266 & $54,3 \%$ \\
Review or revision of notes and books & 47 & $9,6 \%$ \\
Self-assignment of positive and negative sanctions & & \\
\hline
\end{tabular}

Source: Survey applied by the authors

About the frequency of use of technological tools for the development of self-regulated learning, the data show that $54 \%$ of students involved in the study mentioned that they sometimes use technological tools in their self-regulated learning, while $45 \%$ said they always use these resources to enhance their learning, and the remaining $1 \%$ said they never use this type of resource that currently facilitates the processes as shown in figure 2. 


\section{Figure 2}

Frequency of use

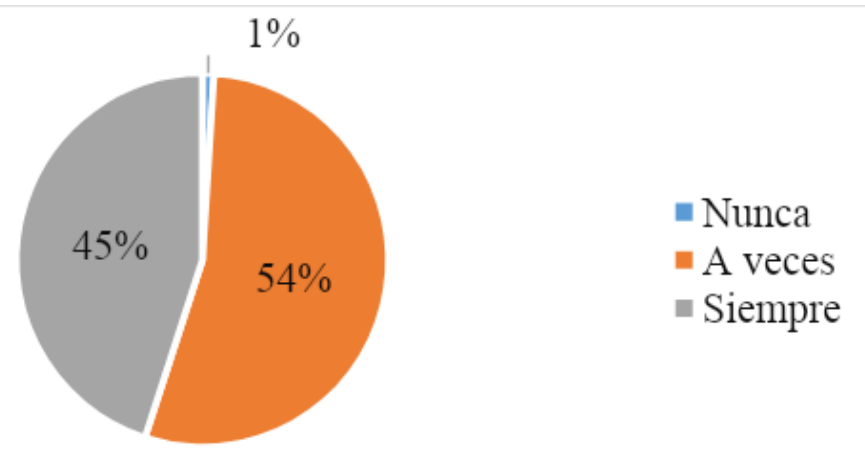

Source: Survey applied by the authors

On the other hand, with regard to the students' perception of whether technological tools facilitate self-regulated learning of the English language, the following findings were found: of the $100 \%$ of students involved, $63 \%$ consider that this statement is always made, while $36 \%$ consider that this facility for learning is only sometimes generated, and finally, $1 \%$ state that the use of the different existing technological tools does not facilitate selfregulated learning of this foreign language in any way as shown in figure 3.

\section{Figure 3}

Ease of self-regulated learning

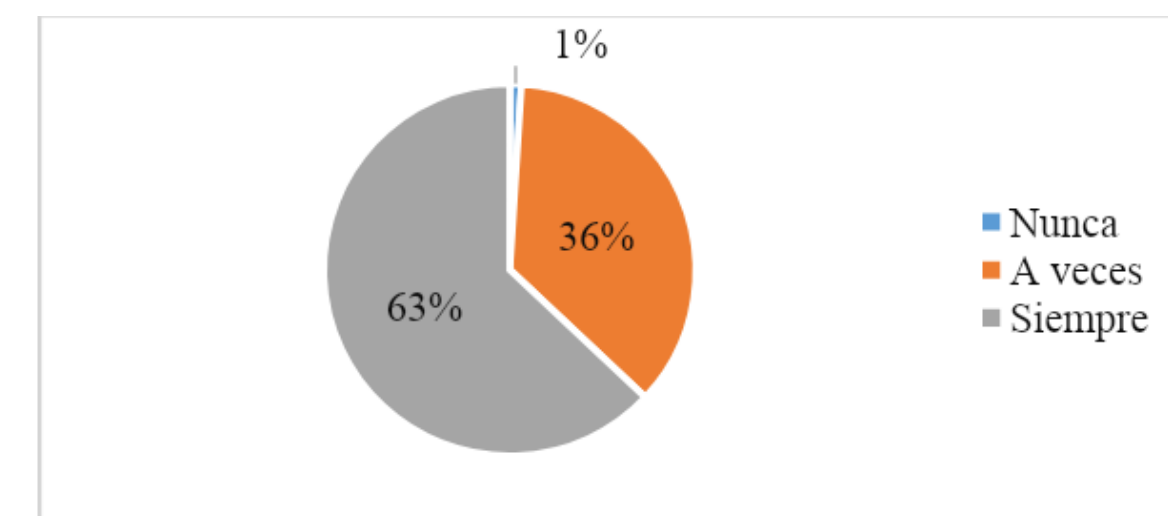

Source: Survey applied by the authors

Finally, to establish the level of correlation between the variables under study, which in this case are technological tools and self-regulated learning, the chi-square test $\left(X^{2}\right)$ was applied, where, according to the calculation carried out by contrasting the observed frequencies with the expected frequencies as shown in table 3, a chi-square value of 15.308 was established. On this basis, with a significance value of 0.05 at 4 degrees of freedom, the tabulated chi-square value is 9.4877. In this sense, as the calculated chisquare value (15.308) is higher than the tabulated chi-square value (9.4877), the working 
hypothesis is accepted, which means, that the use of technological tools facilitates selfregulated English language learning, as shown in table 4 and figure 4.

\section{Table 3}

Observed and expected frequencies

\begin{tabular}{|c|c|c|c|c|c|c|}
\hline & & & \multicolumn{3}{|c|}{$\begin{array}{c}\text { Do you consider that technological } \\
\text { tools facilitate your self-regulated } \\
\text { learning in English? }\end{array}$} & \multirow[t]{2}{*}{ Total } \\
\hline & & & Never & Sometimes & Always & \\
\hline \multirow{6}{*}{$\begin{array}{l}\text { How often do you use } \\
\text { technological tools for the } \\
\text { development of your self- } \\
\text { regulated learning? }\end{array}$} & \multirow{2}{*}{ Never } & Observed & 0 & 0 & 2 & 2 \\
\hline & & Expected & 0,0 & 0,7 & 1,3 & 2,0 \\
\hline & \multirow{2}{*}{ Sometimes } & Observed & 1 & 116 & 148 & 265 \\
\hline & & Expected & 1,1 & 95,7 & 168,2 & 265,0 \\
\hline & \multirow{2}{*}{ Always } & Observed & 1 & 61 & 161 & 223 \\
\hline & & Expected & 0,9 & 80,6 & 141,5 & 223,0 \\
\hline \multirow{2}{*}{ Total } & & Observed & 2 & 177 & 311 & 490 \\
\hline & & Expected & 2,0 & 177,0 & 311,0 & 490,0 \\
\hline
\end{tabular}

Source: Survey applied by the authors

\section{Table 4}

Calculation of chi-square

\begin{tabular}{lrrc}
\hline & Value & df & Asymptotic significance (bilateral) \\
\hline Pearson's Chi-square & $15,308^{\text {a }}$ & 4 & 0,004 \\
Likelihood ratio & 16,128 & 4 & 0,003 \\
Linear by linear association & 11,469 & 1 & 0,001 \\
N of valid cases & 490 & & \\
\end{tabular}

Source: the authors

\section{Figure 4}

Gaussian bell

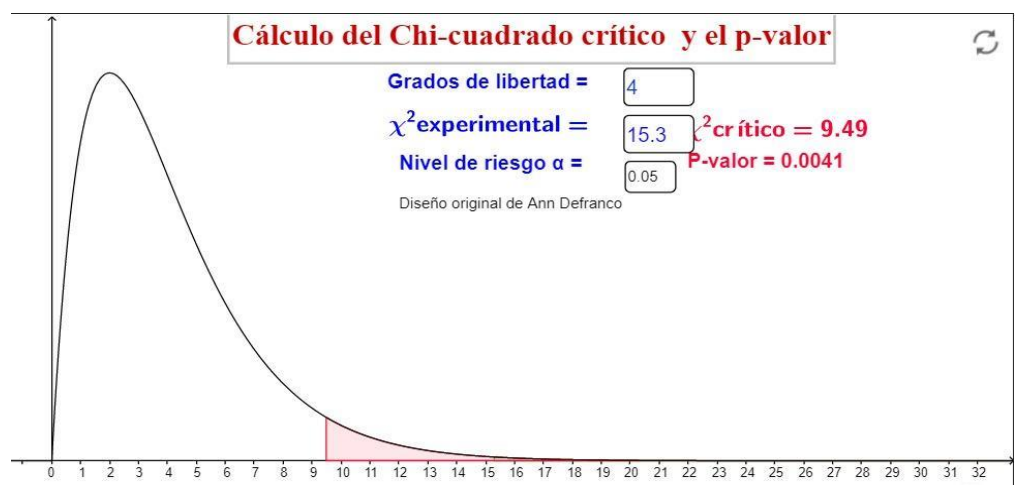

Source: The authors 
With these considerations and the results obtained, the importance of technological tools is statistically proven, given that their application in the academic context facilitates students' learning in general. Against this background, when comparing the results obtained in this research with those collected in other studies, there are marked coincidences, for example, a study carried out by Çelik et al. (2012), for example, a study carried out by the University of California, University of California at Berkeley, found that there were no significant differences in the use of ICTs by men and women for selfregulated learning, and between the language levels of the students. Moreover, in the same context, they add that students mainly use ICT for practicing listening comprehension, vocabulary and writing in English.

From the point of view of Şahin \& Savran (2016), learners take advantage of ICT to regulate different aspects of their language learning experience, especially for the regulation of their engagement with the goal, effective regulation and resource regulation. An important feature of ICT is that it allows learners to study in their own time, at their own pace and at their own level. In this sense, ICT can make the task of learning a language a relaxing and more engaging process, which leads to maintaining learners' interest, enthusiasm and willingness to learn.

On the other hand, to conclude this section, it is important to emphasize that ICT can provide learners with a large number of resources delivered in various formats, among which we can highlight, for example, audio and video material that help learners in the first instance to choose such material according to their needs and preferences in order to facilitate the learning of this foreign language (Arias \& González, 2018; Gooding, 2020).

In the light of the above and contrasting the information obtained, it is evident that the students' acceptance of technology is evident, given that, as they state Supriyono et al. (2020), their use leads them to create technology-mediated language learning in which students use this type of technology (e-learning, YouTube, webs, Podcast, Apps, WhatsApp, films or videos, among other resources to support and expand their learning experiences.

\section{Conclusions}

- This study aimed to identify the students' perceptions regarding the use of technological tools to facilitate self-regulated learning in English. With these considerations and the results obtained, the importance of technological tools is statistically proven, in general, students manifest a great interest in the use and application of these tools. About the frequency of use of technological tools to develop self-regulated learning, all students manifested that they use them. However, the frequency of use varies. The students' interest in the technological 
tools will help universities to create strategies to improve self-regulated learning among pre-service students.

- Self-regulation in learning is a motivational and cognitive process of control, by self-determined goals, through which the learner seeks to adapt to the educational ecosystem with external and internal factors. Self-regulated learning involves goal setting, evaluation of goals, emotional reaction to progress or lack of progress, and management of resources towards goal attainment. Thus, the importance of including these strategies in the teachers' lesson plans.

- Virtual work and virtual education have led to changes in the pre-service formation micro curriculum. For this reason, objectives and pedagogy used in classes need to set simplistic but efficient parameters that help pre-service students self-regulated their learning actively. Since it conceives and awakens the cognitive, motivational/affective and behavioral process to achieve knowledge, skills and abilities, in an effective way in each context.

- In the field of higher education, self-efficacy can be associated with school success, learning with digital technologies or education in personal learning environments. Hence, it is recommended to investigate the role of the university teacher in guidance and feedback to bring about self-regulated learning including variables such as personal initiative, tenacity and adaptability to focus and avoid procrastination.

\section{Acknowledgments}

Thanks to the Technical University of Ambato, to the Research and Development Department (DIDE-UTA) for supporting our research project "SELF-REGULATED LEARNING STRATEGIES WITH TECHNOLOGICAL TOOLS TO HOMOGENIZE ENGLISH PROFICIENCY IN UNIVERSITY STUDENTS IN ZONE 3", approved with Resolution No. UTA-CONIN-2021-0069-R, and being part of the research group: "Research in Language and Education".

\section{Bibliographic References}

Ahmadi, M. (2018). The use of technology in English language learning: a literature review. International Journal of Research in English Education, 3(2), 115-125. https://doi.org/10.29252/ijree.3.2.115

Alqahtani, M. (2019). The use of technology in English language teaching. Frontiers in Education Technology, 2(3), 168-180. https://doi.org/10.22158/fet.v2n3p168 
Andrade Parra, S. Y., Tapia Tapia, M. J., \& Tituana Vásquez, F. del C. (2020). Learning through the use of technological tools in inclusive education and the strengthening of teaching. Scientific Journal, 5(17), 350-369. https://doi.org/10.29394/scientific.issn.2542-2987.2020.5.17.19.350-369

Arias Soto, L. D., \& González Gutiérrez, Y. A. (2018). Digital literacy and basic selfregulation habits in early childhood learning of English as a foreign language. Folios, 49, 177-196. https://doi.org/10.17227/folios.49-9404

Çelik, S., Arkin, E., \& Sabriler, D. (2012). EFL learners' use of ICT for self-regulated learning. Journal of Language and Linguistic Studies, 8(2), 98-118. https://doi.org/10.17263/jlls.16954

Díaz, M., Guiacometto, J., \& Cruz, A. (2018). Use of technological tools for foreign language teaching. Cultura, Educación Y Sociedad, 9(3), 741-748. https://doi.org/http://dx.doi.org/10.17981/cultedusoc.9.3.2018.87

Díaz Mujica, A., Pérez Villalobos, M. V., González Pineda, J. A., \& Núnez Pérez, J. C. (2017). Impact of a self-regulated learning training in university students. Perfiles Educativos, 39(157), 87-104.

https://doi.org/10.22201/iisue.24486167e.2017.157.58442

Escobar Murillo, M., Barragán Murillo, R., Yánez Valle, V., \& Taco Sangucho, N. (2021). Technology as a combined tool for teaching English. Revista Polo Del Conocimiento, 6(9), 1270-1284. https://doi.org/10.23857/pc.v6i9.3109

Flores Rivas, V. R., \& Marquez Alvarez, G. L. (2020). Learning achievement, technological tools and self-regulation of learning in times of Covid 19. Journal of Business and Entrepreneurial Studies, 4(3), 102-109.

https://journalbusinesses.com/index.php/revista/article/view/124/335

Gooding de Palacios, F. A. (2020). Approaches to second language learning: expectations for English language proficiency. Revista Científica Orbis Cógnita, 4(1), 20-38. https://doi.org/10.48204/j.orbis.v4n1a2

Hernandez, R. (2017). Impact of ICT in education: challenges and perspectives.

Propósitos Y Representaciones, 5(1), 325-347.

https://doi.org/http://dx.doi.org/10.20511/pyr2017.v5n1.149

Jiménez Julio, A. (2018). The use of ICT in English language teaching: the case of the School of English, University of Panama. Acción Y Reflexión Educativa Revista, 43, 22-43. http://portal.amelica.org/ameli/jatsRepo/226/2261046002/html/

Lion, C. (2019). The challenges and opportunities of embedding technologies in 
educational practices.

Analysis

of inspiring

cases.

https://www.buenosaires.iiep.unesco.org/sites/default/files/archivos/analisis_comp arativos_-_carina_lion_05_09_2019.pdf

Luján Tubio, M. (2014). Computer-assisted language learning. Advantages and disadvantages. Panorama de Los Estudios Del Discurso En Colombia, 307-321. https://die.udistrital.edu.co/sites/default/files/doctorado_ud/publicaciones/aprendiz aje_lenguas_asistido_por_computador.ventajas_y_desventajas.pdf

Martínez Moreno, P., Vergara Camacho, J., \& Mitzu Itzel, K. (2019). Use of ICTs in English language learning. Electronic Journal of Research in Education Psychology, 17(47), 27-54. https://doi.org/10.25115/ejrep.v17i47.1904

Raja, R., \& Nagasubramani, P. C. (2018). Impact of modern technology in education. Journal of Applied and Advanced Research, 3(1), 33-35. https://doi.org/10.21839/jaar.2018.v3is1.165

Şahin, A., \& Savran, Z. (2016). Self-regulated learning in the digital age: an EFL perspective. Novitas Royas Research on Youth and Language, 10(2), 147-158. https://files.eric.ed.gov/fulltext/EJ1167208.pdf

Suárez, N., \& Custodio, J. (2014). Evolution of information and communication technologies in the teaching-learning process. Revista Vínculos, 11(1), 209-220. https://doi.org/10.14483/2322939X.8028

Supriyono, Y., Saukah, A., Latief, M. A., Widiati, U., \& Suryati, N. (2020). EFL learners' self-regulated learning in a technology-mediated language learning setting. International Journal of Innovation, Creativity and Change, 10(10), 270-285.

\section{LC Ciencia}


El artículo que se publica es de exclusiva responsabilidad de los autores y no necesariamente reflejan el pensamiento de la Revista Conciencia Digital.

\section{\Ciencia}

El artículo queda en propiedad de la revista y, por tanto, su publicación parcial y/o total en otro medio tiene que ser autorizado por el director de la Revista Conciencia Digital.
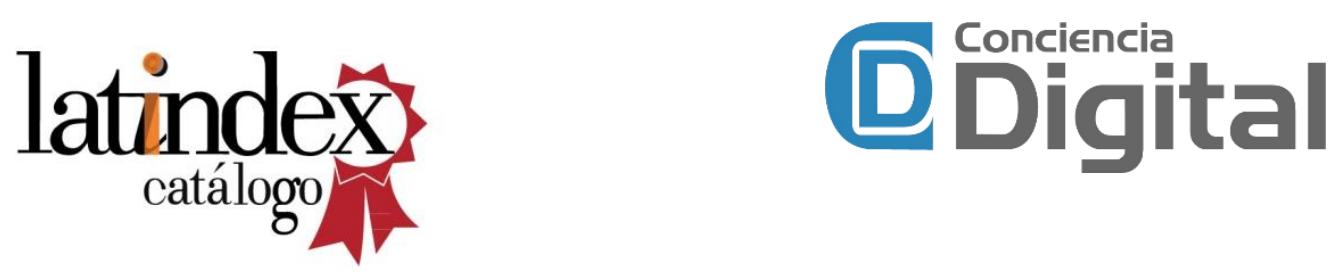

Indexaciones

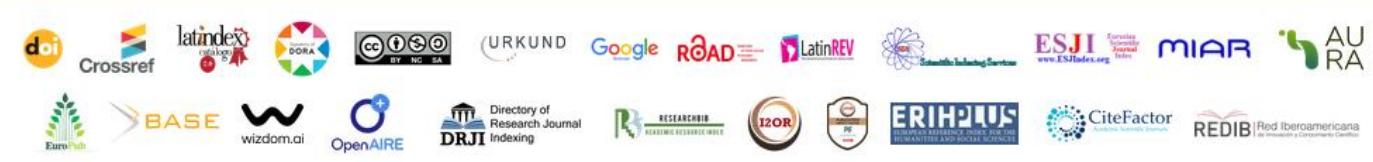

